\title{
Introduction
}

\section{Didaktik and curriculum in ongoing dialogue}

\author{
Ellen Krogh, Ane Qvortrup, and \\ Stefan Ting Graf
}

This volume aims to continue and update an international and intercultural scholarly dialogue that was started in the 1990s. It is the outcome of the first seminar of an international network project, initiated at the University of Southern Denmark in 2018 and funded by the Danish Research Council. While acknowledging the tradition and the salient scholarly contributions to the dialogue, the present network project departs from a very different situation than the original initiative. Today, heading into the 2020s, scholarly contact, shared academic impulses, and cooperation across geographical and geopolitical borders are more frequent than ever; neoliberal policies of quality assurance, accountability, and standardisation are globally shared conditions. Nonetheless, curricular policies and institutional practices - and research approaches - still tend to be shaped by regionally sedimented "constitutional mind sets" (Hopmann, 2008, 2015). In the same way, as Autio has stressed (2014), although there is a shared need for new intellectual, economic, and political theories of learning, curriculum, and reform, important historical differences also have to be considered. Thus, we face a changed and changing landscape that makes it no less important to revive and renew scholarly endeavours of exchange and comparison.

The backdrop to the present volume is the preceding three decades of dialogue and research on cultural and geopolitical differences between the AngloSaxon tradition of curriculum studies and the north-west European Didaktik tradition. There is much knowledge to gain from the first wave of dialogue by way of the conceptual understanding of culturally bound differences. The 1990s forum for dialogue was initiated in the wake of increasing interdependence and harmonisation of education systems across national borders, creating a need for mutual exchange and understanding. Conferences and seminars resulted in comparative research into the historical roots and core notions of the two traditions as well as translations of classical Didaktik texts into English (Gundem and Hopmann, 1998; Hopmann and Riquarts, 1995; Westbury, Hopmann and Riquarts, 2000). The dialogue initiative grew into the new millennium and led to an impressive number of monographs and journal issues. This overwhelming field covers - just to mention some channels and contributions - a large number of studies and several special issues of the Journal of Curriculum Studies, 
as well as special issues of the European Educational Research Journal (2007, 2017), representing work within Network 27 of the European Educational Research Association (EERA). We should also mention edited volumes by Hudson and Meyer (2011); Hopmann et al. (2012); and Siljander, Kivelä and Sutinen (2012). An impressive and influential project is the comprehensive Handbook of Curriculum Studies (2003), edited by William F. Pinar and in the second edition from 2014 revised and extended to include local curriculum studies from 34 countries around the globe. As argued by Pinar:

However hounded by globalization, the curriculum remains nationally based and locally enacted and experienced. Whether that fundamental fact supports tendencies toward cosmopolitanism or provincialism cannot be ascertained apart from studies of national context: historical, social, and cultural.

(2014, p. 12)

Taking stock in 2015, Stefan Hopmann, a pivotal agent in this project, stated that for him the project was primarily "an opportunity to investigate Didaktik and curriculum theory as historically evolved forms of reflection within the social system" (Hopmann, 2015, p. 14, original emphasis). He did, however, characterise the situation in 2015 as complex and dystopian. At the level of policies, he argues that chronic crises in the two traditions have made them "seek salvation" by borrowing core tools from each other, ignoring the experiences and empirical limits of the sources. Hence the continental European education systems have copied the US test culture, while state-based curricular formats have spread in the United States and most of the Commonwealth countries (p. 14). At the level of scholarly work, Hopmann finds that independent researchers within both traditions face an almost insoluble dilemma between involving themselves in, and thereby legitimising, current educational processes that lead to foreseeable 'collateral damage', or being marginalised and thereby letting down the teachers and their students to whom they are accountable in the first place. Operating between these extremes, scholars need to search for options for acting in a didactically responsible manner. Hence, Hopmann concludes:

This leads us, perhaps surprisingly, to the conclusion that it is not less, but much more Didaktik and curriculum theoretical efforts and even more dialogue - the international exchange of experiences - that is needed in order not to lose our orientation on this rocky path.

(Hopmann, 2015, p. 20)

This call for continued and renewed dialogue is echoed by other contemporary voices. Ligozat and Almqvist (2018) suggest that divides within the field may be overcome through two parallel strands of comparative research. One of these strands addresses the relationships between the theoretical constructions 
of research traditions and the epistemologies they are embedded in; this would require the double process of examining the historical and philosophical roots of their emergence and empirically examining how they operate. The second strand addresses empirical issues of difference between educational contexts, school subjects, curricula, and classroom practices.

Tröhler (2014) and Horlacher (2018) take the challenge of comparative research a step further. Tröhler calls attention to the fact that differences between the educational traditions of Didaktik and curriculum are not confined to educational theories but also include the self-construction of educational scholars (Tröhler, 2014, p. 60). He further argues that understanding education means understanding the cultural constructions of the child and of the future citizen. Comparative research needs to reconstruct the genealogies of these constructions, since by learning about other systems of reasoning across times and spaces we gain the "chance of becoming aware of ourselves as historical and cultural constructions" (Tröhler, 2014, p. 65). In her comparative conceptual study of the German Lehrpläne and the anglophone curriculum, Horlacher (2018) shows that these are not just exchangeable terms but imply different belief systems of schooling as well as different styles of reasoning or modes of thinking. She argues that research needs to be configured independently of national theoretical and conceptual traditions in order to provide truly internationally comparative research. Along similar lines of thought to Tröhler, Horlacher suggests that the concept of curriculum or curriculum history may serve for inquiring into the ways societies institutionally organise schooling, socialisation, and the learning opportunities they desire (Horlacher, 2018, p. 12).

The goal of the present network project is to rise to these challenges by framing explorative approaches at three levels. We aim at:

1 exploring how the transnational shifts of the educational systems may be understood in the light of the scholarly dialogue between Didaktik and curriculum - as well as in the light of other relevant differentiations;

2 a investigating how these shifts manifest themselves at different empirical and conceptual levels;

3 and, finally, developing comparative research strategies that serve to throw light on these manifestations while meeting the just-discussed challenges. Thus, we ask what constitutes truly international comparative research that may also elucidate our scholarly self-constructions.

The Danish research community, which initiated and organises the current network project, has not previously hosted activities within the ongoing Didaktik and/or curriculum dialogue. For this research community, historically rooted as it is within the Didaktik tradition, the main frame of international reference is the Nordic countries and Germany and German-speaking countries. Within this cultural configuration, however, the changing educational and 
scholarly landscape has given rise to new theoretical and conceptual developments (Krogh and Qvortrup, this volume), as well as a growing interest in engaging in and contributing to the wider international exchange. The concrete impetus for the network project was, however, radical changes in the educational landscape as well as changes at the level of research funding and academic practices.

At the level of educational policies, over the latest decades, frequent curricular reforms and neoliberal management strategies have transformed the Danish educational system. Core manifestations are the shift from content-based to outcome-based or competency-based study regulations, the enhanced focus on transparency in learning objectives, and the preoccupation with learning data (Ehlers, 2013). The backdrop against which these changes have unfolded is the transnational trend of intensified political interest in education as a contributory factor to economic growth, as in the OECD and the EU. We also see a pattern of importation of educational strategies and tools from the AngloSaxon curriculum tradition.

At the level of research funding and academic practices, the latest decade has witnessed a growth in educational research due, among other things, to a new governmental funding agency focusing on primary and secondary education (cf. Holmberg et al., 2019, p. 10ff.). In parallel, there has been a shift in public funding towards more policy-oriented and strategic research. In the field of academic practices, whereas Danish educational research was previously dominated by qualitative approaches, there has been an enhanced focus on quantitative and mixed-methods methodologies, as well as design and intervention research. Finally, we find a growing international orientation, mainly towards English-language publication channels.

The network project thus originates in a strong call to examine and understand these changes at a more fundamental level than through the optics of immediate before/after dichotomies, and, through this, to develop departures for new research strategies. This call has been echoed in ample indications that Danish educational history is not exceptional, although probably most recognisably in the Nordic region (e.g. Holmberg et al., 2019; Hopmann, 2008) and in the wider field of countries and regions embedded in the Didaktik tradition.

Our network project organises encounters and research exchange, aiming to map existing knowledge on these issues and to develop models for investigating the impact of current educational changes at both theoretical and empirical levels. As documented in the present volume, this call has been met by a diverse range of studies. Interestingly, a prominent trend in the comparative empirical studies is that similarities or continuities rather than expected differences have come to the fore. Still, we have also found studies of conceptual differences between Didaktik and curriculum concerning issues of knowledge and content. The general picture is of a complex field where different new conceptualisations or theoretical approaches are offered in response to 
contemporary transnational discourses and to the changes and challenges of education, schooling, and scholarly knowledge practices.

In the following sections, we investigate the main dualities and developments within the field that are discussed and responded to in this volume. By relating the chapters to a more general picture before introducing them in their own right, we aim to illustrate the exploratory approach of the network. The network dialogues have investigated the current manifestations of reform in different national and local educational contexts and also their impact in these contexts. This cross-dialogue has allowed us to capture the global perspectives without leaving out the concrete manifestations and thus to gain the important insight that contemporary societal challenges worldwide look very similar, even if the cultural and national histories and traditions from which they are approached are very different. The reciprocal movement between the concrete, local/national and global perspectives has, however, also shed light on the complicated pattern of change that globally shared conditions lead to when they encounter the different regionally sedimented constitutional mindsets (Hopmann, 2008, 2015). Thus, we need to repeatedly remind ourselves that the configuration of Didaktik and/or curriculum is a cultural and geopolitical issue, and that it is only appropriate to access and understand the issue as such.

\section{Dualities and developments within the contemporary educational field}

\section{Teaching and learning}

As indicated above, core manifestations of the changing educational landscape are the shift from content-based to outcome-based or competence-based study regulations, and an enhanced focus on learning objectives and learning data. These manifestations have been a central focal point in the dialogues undertaken in the network, and they are also discussed in several chapters in this book.

The issue of learning objectives and data clearly relates to a global tendency to understand schooling primarily as a place of learning and only to a lesser degree a place of education (Horlacher, 2018). As suggested by Biesta (2012, p. 37), we have witnessed a new language of learning in education, a shift from teaching to teaching-and-learning - deliberately written in one word as this is how many people seem to use it nowadays - leading to a 'learnification' of the education system (Biesta, 2010). This trend has deflected attention away from education and teaching, and consequently from the discipline of didactics and from theories of instruction and has placed activities referring to learning at centre stage (Haugsbakk and Nordkvelle, 2007). However, as one delves into the national and local contexts, it is clear that the learnification of the education system can be linked to three parallel and interacting, but distinct 
discourses that coalesce in a shared and growing uncertainty about the aim and content of education as it relates to enhanced societal complexity. As suggested by Yates and Collins, curriculum "has been the subject of vigorous national debate in recent years, debates both about who should control curriculum and about what should be included in subjects" (2010, p. 89). In this volume we find similar references to the current age being determined by uncertainty and contingency (cf. Werler, this volume). Addressing the issue of contingency, Krogh and Qvortrup suggest that contingency management and didactisation are ways to maintain sensitivity towards the complexity of teaching in an age where both concepts of knowledge and content and the aims of education are under pressure in a state of permanent change. Taking a different and phenomenological approach to this issue, Uljens and Kullenberg argue that:

curriculum theory and didactics ... need to explain how to balance and span the gap between the regime of imposed curricula (that is, educational values and means predefined from the perspective of society) and the more open-ended, student-centred idea of freedom in schooling.

(p. 185 , this volume)

In the following, we shall investigate three discourses of learning: the discourse of the knowledge society, promoting the concept of competence the discourse of efficient learning and learners, drawing on educational psychology; and the constructivist discourse of learner-centred education.

The first discourse is related to the growing emergence of the 'knowledge society' (Hargreaves, 2003). Within this discourse, knowledge and learning are regarded as fundamental resources for future development. It made its mark globally with the UNESCO report of 2005, Toward Knowledge Societies: UNESCO World Report, but it must be understood in the light of developments in the Western world in the early part of the twentieth century: the so-called second industrial revolution and the concept of 'human capital' (Becker, 1964; Mincer, 1958). Within this discourse, learning is often associated with the concept of competence, such that:

the concept of competence is not formulated in terms of a particular, educational goal to be achieved but rather in terms of imparting the capabilities necessary for the future, without actually having to specify what this means concretely.

(Horlacher, 2018, p. 9)

We might also say that schooling changes "from an emphasis on knowing things to being able to do things" (Yates and Collins, 2010, p. 89). In the volume, the discourse of the knowledge society is the object of Christensen's study. In comparative analyses of the competence orientations of, respectively, social 
science education in Denmark and political education in Germany, Christensen documents the strong influence of the concepts of competence in the OECD DeSeCo project and the European qualifications framework - arguing, however, that the processes of integrating these concepts should be viewed as new forms of international democracy.

The discourse of efficient learning and learners is inspired by an educational psychology that focuses on cognitive processes, often associated with an interest in the effectiveness in and the effect of education and teaching (Horlacher, 2018). Globally, it manifests itself in the OECD report of 2009, Creating Effective Teaching and Learning Environments: First Results from TALIS. When it comes to effectiveness in education and teaching, the concrete actualisations of this discourse appear, for instance, in a preoccupation with study abilities and proficiencies, study time, etc., in the context of teaching students to become efficient learners in relation to the variety of learning objectives that they meet both inside and outside the education system. As suggested by Horlacher, "The abilities and proficiencies of each student are the undisputed central focus, for the key aim is to ensure that the individual student will be competent for his or her future life" (2018, p. 9). When it comes to the focus on the effect of education and teaching, the very clear example is the increased awareness of results in and the transnational comparisons of PISA, TIMMS, etc., and other kinds of high-stakes testing (Hopmann, 2008). Another example is the strong focus on teachers' efforts to design teaching activities based on meta-studies of the effect of various teaching strategies (Hattie, 2009).

The discourse of efficient learning manifests itself in several book chapters, Deng (p. 25) suggests that the "preoccupation with academic standards, learning outcomes and high-stakes testing" has driven the topic of content out of both policy and academic discussions on teaching and teachers, and he advocates that content be brought back into the conversation. Friesen emphasises similar matters, both when arguing that, thanks to the learning discourse, a differentiated notion of 'content' has been missing from American educational and curricular discourse for decades, and when discussing approaches to remediating this situation. Werler investigates whether the traditional Didaktik narrative of Norwegian teacher education has been substituted by the OECD narrative of learning sciences as necessary requirements for effective learning, and argues for maintaining the Didaktik narrative, since Didaktik competence allows teachers to teach in the complex and contingent world of schools and classrooms.

As indicated, the third discourse - learner-centred education - has a constructivist orientation (Richardson, 2003; Terhart, 2003). This discourse was evident in a number of influential 1990s projects across the globe: From Teaching to Learning (Barr and Tagg, 1995), Responsibility for Your Own Learning (in Norwegian: Ansvar for egen Læring; Bjørgen, 1991), and PEEL, the Project for Enhancing Effective Learning (Baird and Mitchell, 1986). Based on 
a constructivist understanding, it was suggested that in education, "the chief agent in the process is the learner" (Barr and Tagg, 1995, p. 21), which further meant that:

learning environments and activities are learner-centred and learnercontrolled. They might even be 'teacherless'. While teachers will have designed the learning experiences and environments students use - often through teamwork with each other and other staff - they need not be present for or participate in every structured learning activity.

According to Terhart (2003) and Richardson (2003), the 'methodification of didactics' is a general trend and a product of the constructivist paradigm. In this volume the discourse is discussed in Krogh and Qvortrup's chapter, where it is suggested that it has constructed teaching as a phenomenon associated with conservative, authoritarian ideals of education. Deng, referring to Biesta, is also concerned by the observation that teaching is "construed as facilitation of learning that is constructivist and learner-centred, and the teacher as one who no longer passes on content (knowledge) to learners".

The three parallel and interacting, but distinct, discourses of learning identified across the chapters in the book make it clear that although learnification generally represents a conceptualisation of education as an individual project rather than a cultural common good, it is not realised as a distinct onetrack tendency with identical manifestations and consequences in all contexts. Rather, it can be identified as a complicated pattern of change that is based on shared conditions and refers to a growing uncertainty and debate about the aim and content of education. In addition to illustrating how the discourses are addressed in the various chapters, we have also identified different suggestions for dealing with this uncertainty. Aside from the aforementioned, the growth of disciplinary didactics or subject didactics in continental Europe is a manifestation of a historical development within European educational science that addresses global trends of learnification and contributes conceptual and practical tools for the advancement of disciplinary teaching and teacher education, as well as comprehensive scholarly development within the field (cf. Vollmer; Schneuwly; Krogh and Qvortrup, this volume).

\section{Knowledge and content}

In the previous section, learnification was discussed as a challenging condition of the educational project, conceptualising teaching and learning as an individual project rather than a common good. In this section, we discuss what also becomes invisible in learnification discourses: the issue of knowledge and content. 
Historically, the issue of content has been at the heart of educational discussions several times in the Western world, for instance after the second world war in Germany (Tübinger Resolution, 1951), in connection with the Sputnik shock in the United States (1957), and now again as related to the 'knowledge society', where knowledge has become a commodity and a human capital and where nations compete in the ranking of their students' knowledge and skills in international comparative studies (TIMMS, PISA, ICCS, ICILS, PIRLS). Although Ding and Su (this volume) demonstrate from a Chinese perspective that the Western narrative does not apply to all countries, it is still possible to identify a pattern of responses to the policies of economisation, standards, and benchmarks of quantifiable competencies.

We have identified four general responses to these global trends. First, advocating the return to a canon of knowledge. Second, re-actualising the concept of Bildung. Third, engaging in the development of a framework of competences relevant for future challenges. And fourth, arguing for the value of specialised knowledge and for the importance of researching processes of transposition or didactisation. In addition to responding to policies of economisation and the commodification of knowledge, these positions also respond to each other, opposing or integrating aspects. We find, however, that they represent important distinctions within the field, which are explored in the network and in this volume.

The first response issues a new call for knowledge in schooling and education. In the United States, E. D. Hirsch is a well-known advocate for closing the knowledge gap in schools (Hirsch, 2006, 2016). In Germany, publications entitled Bildung: Alles, was man wissen muss (Bildung: All You Need to Know; Schwanitz, 1999) and Die andere Bildung: Was man von den Naturwissenschaften wissen sollte (The Other Bildung: What You Should Know about Natural Sciences; Fischer, 2001) have caused critique and discussion regarding what knowledge matters for becoming an educated individual (Oelkers, 2000). In other countries, similar returns to knowledge canons can be identified, more or less tied to subjects, disciplines, or domains. Although there are differences of focus among these canon approaches as well as in how they are presented, they put forward the idea of concrete and finalised knowledge in the humanities and/or sciences. The canon position is discussed by Uljens and Kullenberg (this volume), who argue that both the promotion of a canonised content of education and the call for competence orientation in education emphasise output-oriented policies, and consequently risk leading to instrumental teaching and learning, while also leaving out the overall Bildung aims of personality, cultural identity, and citizenship.

The second response identified is precisely the re-actualisation of the concept of Bildung. In Germany, Bildung has been debated in many ways and still functions effectively as an important point of reference. Distinct interpretations can be found in Hartmut von Hentig's essay on Bildung (1996) and Manfred 
Fuhrmann's Bildung: Europas kulturelle Identität (Bildung: Europe's Cultural Identity; 2002. Cf. also Vollmer, this volume). In the Nordic countries, the Bildung concept is also advanced in opposition to neoliberal educational policies (Løvlie, 2003; Kemp, 2015). The Dutch scholar, Gert Biesta, in continuation of his rejection of learnification, advocates a post-structural conception of the concept of Bildung (2006). As argued by Rebekka Horlacher in her historical analysis of Bildung, the use of the concept is culturally bound, and different claims and visions are united by ahistorical uses of this flexible concept (2016, p. 131). Horlacher describes how this originally German concept entered the anglophone discussion, lends legitimacy and hope in opposition to the measurable world, gives a refined prestige to the everyday business of education, and even appears in policy papers at the OECD and the World Bank (p. 126ff.).

Three chapters in this book discuss the potential of Bildung-oriented Didaktik in the version developed by Wolfgang Klafki. While heavily criticised from the perspective of historical concept analysis in the German-speaking countries (Tröhler, 2004; Horlacher, 2016), it is interesting that from anglophone perspectives, Klafki's theory appears to contain arguments that have been overlooked in the contemporary German discourse. The chapter by Zongyi Deng compares theories by Michael Young, Joseph Schwab, and Klafki, discussing what distinguishes a theory of knowledge from a theory of content for schooling. According to Deng, the arguments missing from Young's theory concern the justification of a meaningful encounter with content, reflections on his sociological approach, and his ignoring of educational science literature. From the point of view of North America but in a similar fashion, Norm Friesen unfolds the core of the contemporary curriculum discussion (Tyler, Shulman, Pinar, Young) and discusses key conceptual elements of the Bildung-oriented Didaktik of Klafki and Martin Wagenschein. Friesen argues that self-alienation is an indispensable component of Bildung, and he supports this argument by drawing in hermeneutics. As we shall see later, the competence-based curriculum assumes a high relevance for life after school, but the phenomenological foundation of Didaktik presents another conception of the life-world that not only plays a role in relation to learning for life but also underlines students' prior experiences and preconceptions. In this volume, the phenomenological conception of the relation between subjectivity and intersubjectivity is dealt with by Michael Uljens and Tina Kullenberg.

Two further chapters thematise Bildung, albeit less explicitly as a response to current educational policies. In Stefan Ting Graf's contribution, the starting point is the tension between the assumption of Bildung-oriented teaching in Denmark and the recent increasing use of established taxonomies for learning (Bloom, Biggs, Marzano). Graf asks whether it is possible to bridge these two approaches, construing content differently as they do. Finally, in his chapter on general subject didactics, Helmut Johannes Vollmer argues that to prepare teachers and students for the challenges of the twenty-first century, the content specificity of didactics needs strengthening and the notion of 
education as Bildung needs extending and redefining on both a personal and a functional level.

The third response to the policies of economisation, standards, and benchmarks is the increasing research effort that has been devoted to developing frameworks of competences that could play a role in curriculum development. The notion of competence thus informs both discourses of learning and conceptions of knowledge and content. Core examples of this effort are the United States-based initiative for 21st Century Skills (Ananiadou and Claro, 2009) and the OECD project DeSeCo (2005). The notion of competences or broad skills as a way of prescribing the output content of a curriculum is not new. It goes back to the earliest American curriculum developers (e.g. Franklin Bobbitt), who argued that the content of education should provide students with the necessary skills of the older age of the industrial society. Besides the revivals of this approach in the anglophone countries in the 1960s, it was imported to Germany by Saul B. Robinsohn, who also introduced the term 'curriculum' there. A curriculum based on competences or skills is highly focused on what students should be able to perform in the workplace and in public and private life. The competence concept, however, is currently also applied to disciplinary educational goals of further education, as in Scandinavian teacher education curricula (cf. Werler, this volume). Once entrenched in curricula, however, the concept could be said to be losing some of its original idea.

Two contributions in this book deal with competence-oriented curricula, investigating the transforming processes that take place when the concept of competence is transplanted to teacher education in Norway (Werler, this volume) and when it is integrated in political education/social science education in Germany and Denmark (Christensen, this volume). These two chapters emphasise the importance of studying the transformations of seemingly identical concepts in concrete contexts.

The fourth response to current educational policies is to argue for the importance of specialised knowledge, not least for the importance of research into processes of transformation or transposition of disciplinary knowledge into school subjects (cf. Schneuwly, this volume). Starting with analyses of contemporary competitive knowledge economies, it is further argued that what specialised knowledge agents (such as teachers and educational researchers) need to prioritise in the current environment is discussing, reflecting on, and developing specialised knowledge and content to meet permanent pressures for change and reform (Ongstad, 2006). As documented in the present volume, within this response, theories of the transformation of knowledge into content are already informing educational research programmes (Schneuwly; Vollmer; Krogh and Qvortrup, this volume). As is elaborated later, these theories have given rise to paradigmatic developments within the scholarly field of didactics.

This analysis of responses to contemporary challenges within the field of content indicates both important distinctions and shared conditions of uncertainty as to the intergenerational purpose of schooling. Although the distinctions may 
perhaps be problematised and naturally call for more extensive elaboration, this attempt at charting the field will hopefully give rise to further investigation and discussion of knowledge and content as a core aspect of education and schooling.

\section{Didaktik and didactics: translations, developments, and conceptualisations}

In this volume, the construct Didaktik and/or curriculum is both an important general reference and a concrete frame for comparative studies. However, whereas the field of curriculum studies is not represented in the specialised investigations of these chapters, developments within the field of Didaktik or didactics are in focus in several of the chapters. The backdrop to this imbalance is not just the circumstantial fact that our network project is hosted within the cultural frame of Didaktik. More substantially, this book offers a strong argument for the importance of representing recent paradigmatic shifts within the Didaktik field to the wider educational community. At issue are scientifically specialised responses to current educational challenges that contribute conceptual innovation as well as tools for reflective practice within teaching and teacher education.

The field of Didaktik, or didactics, confronts difficult issues of translation in the anglophone educational community. At the time of the first wave of Didaktik and/or curriculum dialogue, the German spelling of Didaktik was adopted in order to sustain connotations such as the "comprehensive intertwining of action and reflection, practice and theory" (Gundem and Hopmann, 1998, p. 2). As Gundem and Hopmann explained, the English term 'didactics' is "generally avoided in Anglo-Saxon educational contexts since it refers to practical and methodological problems of mediation and does not aim at being an independent discipline, let alone a scientific or research program" (p. 2). A parallel translation issue also arises for the key term 'Bildung', which likewise has no counterpart in English that conveys its meaning within the Didaktik tradition. Added to this, both Didaktik and Bildung are historical and cultural configurations that have long histories of interpretation and impact within different national and regional contexts (cf. Horlacher and De Vincenti, 2014; Horlacher, 2016).

Whereas Bildung is now accepted as the established term in English-language contexts and debates, this is not the case for Didaktik. As will be obvious from the book chapters, for very good reasons, both 'Didaktik' and 'didactics' have become established terms. 'Didaktik' is generally used when referring to the Didaktik tradition of north-west Europe as such, and this programmatic usage is sustained in the present book. But if more recent developments in the field are to be captured, a more differentiated terminology is required. Regions and nations have met transnational challenges differently and have configured their fields of teacher education and academic educational institutions differently. 
The cultural construction 'Didaktik' is too monolithic to allow us to distinguish between different national educational cultures. Hence, despite the derogatory and narrow connotations, the non-anglophone educational community has ventured to reinterpret the term 'didactics' to become a common English-language denominator of this more differentiated educational field.

The term 'didactics' grows out of yet another differentiation, namely in the academic field. As elaborated in several of the chapters, in the later decades of the twentieth century specialised school-subject didactics grew to become an independent academic field of didactics in response to the tertiarisation of teacher education and the massification of secondary education (Schneuwly, this volume; cf. Vollmer; Krogh and Qvortrup, this volume). This field has grown in importance during the latest decades in response to the trends just discussed: learnification, the adoption of competency aims at the curricular level, and growing pressure on established knowledge fields to adapt to economic calls for utility and productivity (Krogh and Qvortrup, this volume; cf. Deng; Friesen, this volume). The field has grown in several dimensions. Single-subject teachers and researchers develop specialised didactics exploring the specific teaching, learning, and literacies of their knowledge fields in processes of communicative reflection or didactisation (Ongstad, this volume; cf. Krogh and Qvortrup, this volume). At the scholarly level, comparative or general disciplinary/subject didactics has grown to become an important further organisation of the field (Vollmer; Schneuwly; Krogh and Qvortrup, this volume).

Disciplinary didactics is a young field and still developing fast at the scholarly level. From the status of being a subfield of general didactics focusing mainly on instructional methodology, it has established itself as an independent field next to general didactics (cf. Vollmer; Krogh and Qvortrup, this volume), or even in the francophone context as the singular field of didactics (Schneuwly). We need to keep this in mind as the backdrop to the various different translations of the field in this book. As reflected in the chapters, the francophone didactiques disciplinaires indicate a field where there is a focus on processes of transposition of knowledge from the academic disciplines to the school subjects; further, research within this tradition is oriented towards how the didactic system functions, rather than towards transforming and improving it (cf. Schneuwly, this volume). The German subject didactics and general subject didactics indicate a focus on school-subject teaching and learning, together with a research focus on developing and improving teaching and learning within the content areas. And, finally, the Danish and Norwegian disciplinary didactics indicates a focus on established knowledge in school subjects, but also in the wider societal context; here the research focus is predominantly exploratory, although interventionist research is also found (Krogh and Qvortrup; Ongstad, this volume).

As discussed by Vollmer and Krogh and Qvortrup, the field of general didactics faced backlashes during the period when disciplinary didactics was growing into an independent field. According to Vollmer, within the German context, to some extent general didactics is being replaced by socio-psychological 
approaches with sophisticated models of teaching and outcome orientation. In the Danish context, however, whereas the general didactics field was hit harder by the learnification agenda than disciplinary didactics, general didactics has regained a fairly strong position, establishing a research community in which systems-theoretical didactics is the theoretical basis and empirical research is a new focus.

Uljens and Kullenberg (this volume) introduce school didactics as a delineation of disciplinary didactics that takes the specific school context for teaching and learning into account. The fact that learning opportunities are now so widespread that schools have lost their unique character as 'temples of learning' may have contributed to a crisis of general didactics, but for Uljens and Kullenberg it has created a need for renewed exploration of what kind of pedagogical knowledge is required for understanding teaching, studying, and learning in schools. Welcoming the rediscovery of teaching as a problem in didactics and curriculum research, and emphasising the central focus on content, their chapter declares their interest in developing a 'non-affirmative school didactics' as a theory that allows for concepts to be refined as analytical tools for the educational field.

\section{Didaktik and/or curriculum: future opportunities and challenges}

A highly interesting Chinese perspective on the Didaktik and/or curriculum dichotomy is found in Ding and Su's chapter. Their study shows how questions of didactics or curriculum have historically been related to overarching Chinese political and cultural preferences: perceived by Chinese scholars as 'Western' concepts, they were seen as culturally the same. Viewed from this outside perspective, our endeavour needs to be expanded so as to include questions about what is shared, historically as well as in the present age. Ding and Su's important contribution makes a strong call for expanding the intellectual perspectives and the geopolitical scope of the network project.

Several other studies in the present book may add to this agenda. This goes for Deng's contribution, where he brings together the intellectual contributions made by Schwab and Klafki to form arguments for bringing content back into the discussion, and for Tahirsylaj's chapter, which concludes that differences across both Didaktik and curriculum countries regarding teacher responsibility point towards a continuum rather than a dichotomy.

In accordance with the exploratory ambition of the network dialogues, our immediate future aim for the next stage of the network is to take more specific issues as gateways to investigating differences in historical tradition, geopolitical position, and scholarly approach. Thus we shall focus on two urgent global challenges for the educational project: Bildung/the educated subject in the light of sustainability, and Knowledge, content, and disciplinarity in the postfactual era. Here we interpret sustainability in a wide sense, as incorporating 
issues of climate and environment, society, democracy and welfare, and cultural and individual diversity. We also suggest a similarly wide understanding for 'the post-factual era', which may address issues of fake news, access to vast amounts of internet information, and pressure on established disciplinary knowledge and expertise to prove its relevance and worth. These are the two highly topical themes that will guide the next stage of the network's investigations, both in symposium and publication form.

\section{Introduction to the individual chapters}

The first section of the volume discusses contemporary educational issues in the light of the curriculum/Didaktik traditions.

Zongyi Deng argues that content - knowledge selected into the curriculum has disappeared from current global policy discourse concerning teaching and teachers, and he attempts to bring content back into the conversation on teaching and teachers. With reference to the work of Michael Young and his colleagues concerning 'bringing knowledge back in', Bildung-centred Didaktik, and Joseph J. Schwab's curriculum thinking, the chapter yields an educational and curricular understanding of teaching and teachers, by making three arguments. First, teaching (content) is an 'intergenerational' task that is vital to social reproduction and innovation. Second, by way of the meaningful encounter between content and students, teaching contributes to students' self-formation and the development of human powers and dispositions. Third, teaching is a practical, interpretive act that calls for curriculum thinking that is centred on the 'what' (content) and the 'why' (purpose) of teaching.

Tobias Werler's chapter examines the hypothesis that the traditional core narrative of Didaktik in Norwegian teacher education has been replaced by an OECD narrative of learning sciences. Based on narrative methodology and historical and theoretical analyses of the Didaktik and learning-science traditions, Werler conducts "narrative curriculum analysis" of Norwegian teacher education, with particular focus on the core discipline, Pedagogy and Pupil Knowledge (PPK). This subject was traditionally Bildung-led, teacher-oriented, and content-focused. The present curriculum documents are, however, dominated by the concept of learning (in various forms and shapes). Werler concludes that the present PPK curriculum stands out as a hybrid construct amalgamating Didaktik with learning-science knowledge, a "palimpsest of broken narratives" which does not resolve the question of what knowledge of pedagogy future teachers need to have to develop and deliver good teaching.

In his chapter, Norm Friesen departs from an analysis of what he views as a "missing link" in American educational discourse since the rise of behaviourism in the early twentieth century, namely an understanding of what makes instructional content specifically educational. In the face of this neglect of content in American approaches to psychology, instruction, and design, Friesen conducts a critical analysis of contemporary configurations of learning theory 
and curriculum theory and sets out to develop an account of curricular content as material that is inherently pedagogical. With reference to Lee Shulman's concept of "content knowledge", Michael Young's "powerful knowledge", and Wolfgang Klafki's understanding of didactic preparation, Friesen suggests a general "hermeneutic" theory of knowledge transmission that is commensurate with the understanding of curricular content as inherently pedagogical material.

Stefan Ting Graf enters into a dialogue with the increased interest in taxonomies that in Denmark has followed in the wake of the 2015 shift to a goaloriented curriculum for the Folkeskole (primary and lower secondary level). Often, the references for working with taxonomies are previous works from the anglophone educational context, referring to concepts of teaching and learning which, according to Graf, cannot adequately cover the overriding aims of the Danish Folkeskole because they leave out the central curricular notions of knowledge and generic skills, deep learning and progression, as well as content and purpose. In the chapter, Graf examines the taxonomic thinking of Bloom's taxonomy and the SOLO taxonomy. With reference to Wolfgang Klafki and Martin Wagenschein, he suggests a taxonomy for general Bildung, founded in a phenomenological understanding of learning in the sense of categorical learning.

In his chapter, Anders Stig Christensen discusses the decision-making processes that have generated social science curricula in Germany and Denmark. In both cases, the process of developing curricula is tied to international and national standards that support outcome- or competence-based curricula. This apparent uniformity, however, covers significant diversity, which Christensen documents in his comparative analysis of how the international frameworks have been interpreted and transformed by local/national stakeholders. Not only do the subjects differ in scope from one country to another, but the applied concept of competence differs significantly, as do the role and influence of local actors. Christensen raises the question whether curriculum developments should be analysed from an international point of view, taking into account overriding issues of democracy and the national traditions of curriculum or Didaktik. To understand this complex process that involves more than one demos, he suggests the concept of demoi-cracy.

The second section introduces the emergence of recent conceptual and organisational developments within the field of Didaktik. These chapters provide insight into the continental European construction of educational science as an independent scientific field: one that undergoes paradigmatic shifts in response to changes within the educational field.

Ellen Krogh and Ane Qvortrup's chapter builds on the case of didactics in Denmark. They suggest that contemporary general and disciplinary didactics should be conceptualised as complementary, meta-reflective scholarly fields that may contribute answers to present challenges for schooling and for educational 
research. Thus, there is a need for educational agents to master processes of 'contingency management' and 'didactisation', notions inspired respectively by sociological systems theory and semiotic communications theory. From these positions, the Danish scholarly fields of general and disciplinary didactics have succeeded in establishing a fruitful, explorative dialogue within so-called laboratories for eclectic, meta-reflective didactics.

In his chapter, Helmut Johannes Vollmer argues that in Germany, traditional Bildung-oriented general didactics has lost its orientating function for teacher education and professionalisation. This he attributes to a shortfall in empirical orientation, the disappearance of content from the discussion, and a toonarrow definition of Bildung as a merely personal dimension of education. In recent decades, however, the field of 'subject didactics' has grown to meet these weaknesses, not just through advancements in individual subject didactics, but also, and not least, through the organisation and scholarly progress of the field of 'general subject didactics'. An important result here has been the development of an expanded notion of Bildung that covers a functional as well as a personal dimension.

The setting for Bernard Schneuwly's chapter is the multicultural country of Switzerland, where two different scientific cultures, the germanophone and the francophone, meet. Schneuwly introduces the latter of these two fields, the didactiques disciplinaires, an important school of thought, yet less known in the Didaktik/ curriculum dialogue. The driving forces behind the didactiques disciplinaires were the tertiarisation of teacher education and the massification of secondary education from the 1960s, accompanied by a more marked organisation into disciplines and profound transformations of curricular contents. At the core of disciplinary didactics lie the questions of the transposition and the teaching of knowledge. How does knowledge become teachable and learnable through teaching? How is it taught and learned through teaching? These questions are addressed by a theoretical body of concepts shared by the academic field. Through the overarching concepts of didactic transposition and the didactic system, this body of knowledge is introduced and exemplified in the chapter.

The chapter by Michael Uljens and Tina Kullenberg brings up conceptual missing links between life-world phenomenology and educational theory. Against the backdrop of a broad and context-sensitive understanding of school didactics in conjunction with a hermeneutic, Bildung-centred tradition of theorising education, they explore the paradox of life-world in the educational endeavour. The authors discuss the relation between subjectivity and intersubjectivity and ask how we can conceptualise an initial shared life-world of different individuals and an educational process where a shared world leads to students becoming unique. To grasp the paradox, Uljens and Kullenberg suggest a nonaffirmative theory of education, centring on the classical didactic concept of Bildsamkeit. The core idea of this concept is to secure the freedom to transcend the shared world for both teacher and learner. 
The final section introduces three chapters that, each in a different way, offer critical perspectives on the theme of the present publication and through this raise inspiring challenges for the project.

The chapter by Bangping Ding and Xun Su argues that in the Chinese perspective, both Didaktik and curriculum studies were seen as Western traditions. By presenting and analysing the historical trajectories of the various influences on mainland China and the content of influential publications, the authors underline the importance of ideological, political, and cultural forces on the framing of the didactical field. Following the consecutive introductions in the early twentieth century first of Didaktik and then of curriculum theory, both traditions somehow coexist, although curriculum studies became predominant after the Cultural Revolution. Ding and Su pinpoint misinterpretations in the import of both traditions, and they suggest conceiving didactics as an independent university discipline with the obligation of enacting academic reflection on the complementarity of the two traditions and relating this to challenges in educational policy and practice. At the same time, the authors make a strong argument for the revitalisation of Chinese harmonism, based on Confucianism, for such a blended discipline.

In his chapter, Armend Tahirsylaj draws on data from PISA 2015 for an empirical comparison of teachers' responsibility for the intended, taught, and tested curriculum across six Didaktik and six curriculum countries. On the basis of the assumption that the theoretical and cultural differences between the Didaktik and curriculum traditions are still in play in the countries he surveys, Tahirsylaj tests the hypothesis that teachers in Didaktik countries are ascribed greater responsibility for all three aspects of the curriculum. Despite some indications of difference, however, the results of his study contest the theoretically framed dichotomy and point rather to a continuum in Didaktik and curriculum countries. The results testing a second hypothesis, that higher teacher responsibility impacts students' science performances, remain discouraging, and call for follow-up studies.

In the final chapter of the volume, Sigmund Ongstad raises a critical and overarching perspective on curriculum studies and Didaktik, arguing that both traditions suffer from low awareness of or even direct blindness to the constitutive relation between education and language/communication $(\mathrm{L} \& \mathrm{C})$ as well as the intimate relationship between disciplinarity and discursivity. Ongstad introduces a semiotic and systemic conceptualisation of 'language and communication' and documents its capacity to throw light on basic aspects and differences of curricula as well as schools of educational thought. He suggests that this expanded theory of L\&C should be an integral part of disciplines of general theory of knowledge within master's and doctoral studies of educational sciences. In the final section of his chapter, Ongstad further shows how aspects of this conceptualisation of education are addressed in the chapters by Friesen, Krogh and Qvortrup, Vollmer, Schneuwly, and Uljens and Kullenberg. 


\section{Note}

1 For this reason, we have chosen to refrain from the standard practice of italicising Didaktik and Bildung in this volume.

\section{References}

Ananiadou, K. and Claro, M. (2009). 21st century skills and competences for new millennium learners in OECD countries. OECD Education Working Papers. No. 41, Paris: OECD Publishing. https://doi.org/10.1787/218525261154.

Autio, T. (2014). The internationalization of curriculum research. In: W. Pinar, ed., International handbook of curriculum research, 2nd ed. New York and London: Routledge, pp. 17-31.

Baird, J. R. and Mitchell, I. J., eds. (1986). Improving the quality of teaching and learning: An Australian case study. The PEEL project. Melbourne: The PEEL Group, Monash University.

Barr, R. B. and Tagg, J. (1995). From teaching to learning: A new paradigm for undergraduate education. Change, 27(6), pp. 13-25.

Becker, G. (1964). Human capital. New York: Columbia University Press.

Biesta, G. (2006). Beyond learning: Democratic education for a human future. Boulder, CO: Paradigm.

Biesta, G. (2010). Good education in an age of measurement: Ethics, politics, democracy. Boulder, CO: Paradigm.

Biesta, G. (2012). Giving teaching back to education: Responding to the disappearance of the teacher. Phenomenology \& Practice, 6(2), pp. 35-49.

Bjørgen, I. A. (1991). Ansvar for egen laring: Den professionelle elev og student [Responsibility for your own learning: The professional pupil and student]. Trondheim, Norway: Tapir.

Ehlers, S. (2013). Globalisering, vidensøkonomi og konkurrenceevne: Om restruktureringen af det danske uddannelsessystem [Globalization, knowledge economy, and competitiveness: On the re-structuring of the Danish educational system]. In: S. Wiborg and J. E. Larsen, eds., Verden i skolen, skolen i verden. Arbog for uddannelseshistorie 2013 [The world in the school and the school in the world. Yearbook for educational history 2013]. Copenhagen: The Association for School and Education History, 47, pp. 21-35.

Fischer, E. P. (2001). Die andere Bildung: Was man von den Naturwissenschaften wissen sollte [The other Bildung: What you should know about natural sciences]. Munich: Ullstein.

Fuhrmann, M. (2002). Bildung: Europas kulturelle Identität [Bildung: Europe's cultural identity]. Ditzingen: Reclam.

Gundem, B. B. and Hopmann, S. (1998). Introduction: Didaktik meets curriculum. In: B. B. Gundem and S. Hopmann, eds., Didaktik and/or curriculum: An international dialogue. Bern: Peter Lang, pp. 1-8.

Hargreaves, A. (2003). Teaching in the knowledge society. New York and London: Teachers College Press.

Hattie, J. (2009). Visible learning: A synthesis of over 800 meta-analyses related to achievement. New York and London: Routledge.

Haugsbakk, G. and Nordkvelle, Y. (2007). The rhetoric of ICT and the new language of learning: A critical analysis of the use of ICT in the curricular field. European Educational Research Journal, 6(1), pp. 1-12. https://doi.org/10.2304/eerj.2007.6.1.1.

Hirsch, E. D. (2006). The knowledge deficit: Closing the shocking education gap for American children. Boston, MA: Houghton Mifflin. 
Hirsch, E. D. (2016). Why knowledge matters: Rescuing our children from failed educational theories. Cambridge, MA: Harvard Education Press.

Holmberg, P., Krogh, E., Nordenstam, A., Penne, S., Skarstein, D., Karlskov Skyggebjerg, A., Tainio, L. and Heilä-Ylikallio, R. (2019). On the emergence of the L1 research field: A comparative study of $\mathrm{PhD}$ abstracts in the Nordic countries 2000-2017. L1-Educational Studies in Language and Literature, 19, pp. 1-27. https://doi.org/10.17239/L1ESLL-2019. 19.01.05.

Hopmann, S. T. (2008). No child, no school, no state left behind: Schooling in the age of accountability. Journal of Curriculum Studies, 40(4), pp. 417-456. https://doi.org/10.1080/ 00220270801989818.

Hopmann, S. T. (2015). 'Didaktik meets curriculum' revisited: Historical encounters, systematic experience, empirical limits. Nordic Journal of Studies in Educational Policy, 2015(1). https://doi.org/10.3402/nstep.v1.27007.

Hopmann, S. T., Hudson, B., Seel, N. and Zierer, K., eds. (2012). International perspectives on the German didactics tradition. Jahrbuch für Allgemeine Didaktik 2012, thematic section. Baltmannsweiler: Schneider Verlag Hohengehren.

Hopmann, S. T. and Riquarts, K. (1995). Didaktik und, oder Curriculum: Grundprobleme einer internationalen vergleichenden Didaktik [Didaktik and/or curriculum: Basic problems of an internationally comparable Didaktik]. Zeitschrift für Pädagogik, Beiheft [additional volume] 33, pp. 9-34.

Horlacher, R. (2016). The educated subject and the German concept of Bildung: A comparative cultural history. New York and London: Routledge.

Horlacher, R. (2018). The same but different: The German Lehrplan and curriculum. Journal of Curriculum Studies, 50(1), pp. 1-16. https://doi.org/10.1080/00220272.2017.1307458.

Horlacher, R. and De Vincenti, A. (2014). From rationalist autonomy to scientific empiricism: A history of curriculum in Switzerland. In: W. Pinar, ed., International handbook of curriculum research, 2nd ed. New York and London: Routledge, pp. 476-492.

Hudson, B. and Meyer, M., eds. (2011). Beyond fragmentation: Didactics, learning and teaching in Europe. Leverkusen Opladen: Barbara Budrich.

Kemp, P. (2015). Lognen om dannelse: Opgor med halvdannelsen [The lie about Bildung: Breaking with the half-Bildung]. Copenhagen: Tiderne Skifter.

Ligozat, F. and Almqvist, J. (2018). Conceptual frameworks in didactics - Learning and teaching: Trends, evolutions and comparative challenges. European Educational Research Journal, 17(1), pp. 3-16. https://doi.org/10.1177/1474904117746720.

Løvlie, L. (2003). The promise of Bildung. In: L. Løvlie, K. P. Mortensen and S.-E. Nordenbo, eds., Educating humanity: Bildung in postmodernity. Oxford: Blackwell, pp. 151-170.

Mincer, J. (1958). Investment in human capital and personal income distribution. The Journal of Political Economy, 66(4), pp. 281-302.

OECD (Organisation for Economic Co-operation and Development) (2005). DeSeCo: The definition and selection of key competencies. Executive Summary. Available at: www.oecd. $\mathrm{org} /$ education/skills-beyond-school/definitionandselectionofcompetenciesdeseco.htm [Accessed 16 May 2020].

OECD. (2009). Creating effective teaching and learning environments: First results from TALIS (1938-1840). Available at: www.oecd.org/berlin/43541655.pdf [Accessed 16 May 2020].

Oelkers, J. (2000). Rezension: Dietrich Schwanitz: Bildung: Alles, was man wissen muss. Manfred Fuhrmann: Der europäische Bildungskanon des bürgerlichen Zeitalters [Review: Dietrich Schwanitz: Bildung: All you need to know. Manfred Fuhrmann: The European canon of Bildung in the bourgeois age]. Zeitschrift für Pädagogik, 46(3), pp. 453-457. 
Ongstad, S. (2006). Fag i endring: Om didaktisering af kunnskap [Subjects in change: On didactisation of knowledge]. In: S. Ongstad, ed., Fag og didaktikk i larerutdanning: Kunnskap $i$ grenseland [Subjects and didactics in teacher education: Knowledge in borderland]. Oslo: Scandinavian University Press, pp. 19-57.

Pinar, W. (2003). International handbook of curriculum research. New York and London: Routledge.

Pinar, W. (2014). International handbook of curriculum research, 2nd ed. New York and London: Routledge.

Richardson, V. (2003). Constructivist pedagogy. Teachers College Record, 105(9), pp. 1626-1640.

Schwanitz, D. (1999). Bildung: Alles, was man wissen muss [Bildung: All you need to know]. Frankfurt am Main: Eichborn.

Siljander, P., Kivelä, A. and Sutinen, A. (2012). Theories of Bildung and growth: Connections and controversies between continental European educational thinking and American pragmatism. Rotterdam: Sense.

Terhart, E. (2003). Constructivism and teaching: A new paradigm in general didactics? Journal of Curriculum Studies, 35(1), pp. 25-44. https://doi.org/10.1080/00220270210163653.

Tröhler, D. (2004). Allgemeine Didaktik revisited [General didactics revisited]. Beiträge zur Lehrerbildung, 22(2), pp. 157-170.

Tröhler, D. (2014). International curriculum research: Why and how? In: W. Pinar, ed., International handbook of curriculum research, 2nd ed. New York and London: Routledge, pp. 60-66.

UNESCO. (2005). Toward knowledge societies: UNESCO world report. Condesur-Noireau, France: United Nations Educational, Scientific and Cultural Organization. Available at: https://unesdoc.unesco.org/ark:/48223/pf0000141843 [Accessed 16 May 2020].

von Hentig, H. (1996). Bildung: Ein essay. Munich: Carl Hanser.

Westbury, I., Hopmann, S. and Riquarts, K. (2000). Teaching as a reflective practice: The German Didaktik tradition. Mahwah, NJ: Lawrence Erlbaum.

Yates, L. and Collins, C. (2010). The absence of knowledge in Australian curriculum reforms. European Journal of Education, 45(1), pp. 89-102. https://doi.org/10.1111/j.1465-3435.2009. 01417.x. 